\title{
As CEBs em Aparecida. A retomada de um modelo de evangelização?
}

\author{
CEBs in Aparecida. The resumption \\ of a model of evangelization?
}

Celso Luiz Tracco*

Resumo: Este artigo discute o modelo de evangelização das Comunidades Eclesiais de Base no Brasil e sua possível retomada conforme discutido na Conferência de Aparecida. Inicia com o período pré-CEBs e suas experiências inéditas de evangelização. Analisa o desenvolvimento e crescimento das CEBs, e sua queda como modelo de eclesiologia. E termina com uma reflexão sobre a possibilidade de uma retomada desta forma de evangelização conforme sugere 0 Documento de Aparecida.

Palavras-chave: Evangelização; Sociedade; Brasil; Comunidade.

Abstract: This article discusses the model of evangelization of the Christian Base Communities in Brazil and its possible comeback as discussed in the Aparecida Conference. It starts with the pre-CEB period and their inedited evangelization experiences. It analyzes the development and growth of CEBs and its decline as an ecclesiological model. It concludes with a reflection about the possibility of a revival of this form of evangelization as suggested by the Aparecida Document.

Keywords: Evangelization; Society; Brazil; Community.

\footnotetext{
* Celso Luiz Tracco é Mestre em Teologia Sistemática e professor no UNISAL. E-mail: contato@celsotracco.com.br
} 


\section{Introdução}

A V Conferência do Episcopado Latino Americano e do Caribe, realizada em Aparecida, em 2007, procurou retomar a eclesiologia do Vaticano II e "propõe a grande tarefa de proteger e alimentar a fé do povo de Deus e recordar também aos fiéis deste Continente que, em virtude de seu batismo, são chamados a ser discípulos e missionários de Jesus Cristo". ${ }^{1}$ O Documento conclusivo ressalta a urgência de se realizar muitas demandas ligadas à evangelização, das quais destacamos:

- É urgente uma formação específica dos leigos, para que possam ter incidência significativa nos diferentes campos, sobretudo "no vasto mundo da política, da realidade social e da economia, como também da cultura, das ciências e das artes, da vida internacional, dos meios de comunicação e de outras realidades abertas à evangelização";

- É urgente criar estruturas que consolidem uma ordem social, econômica e política na qual não haja iniquidade e onde haja possibilidades para todos; ${ }^{3}$

- A santidade não é fuga para o intimismo ou para o individualismo religioso, tampouco abandono da realidade urgente dos grandes problemas econômicos, sociais e políticos da América Latina e do mundo, e muito menos fuga da realidade para um mundo exclusivamente espiritual. ${ }^{4}$

Como todos os batizados são chamados a serem discípulos missionários, Aparecida insiste muito na formação dos leigos, ${ }^{5}$ afirmando ser necessário que o leigo seja levado em consideração com espírito de comunhão e participação. O Documento também aborda incisivamente a renovação das estruturas eclesiais, visando uma maior eficiência no trabalho evangelizador:

1 CONSElho EPISCOPAl LATINO AMERICANO. Documento de Aparecida. São Paulo: Paulus, 2007, n. 10. Daqui em diante DAp.

2 DAp. n. 283.

3 DAp. n. 384.

4 DAp. n. 148.

5 DAp. n. 174, 212, 213, 283, 345. 
- Deve-se adotar um estilo pastoral adequado à realidade urbana com atenção especial à linguagem; ${ }^{6}$

- Uma setorização das paróquias em unidades menores que permitam a proximidade e um serviço mais eficaz; ${ }^{7}$

Particularmente no mundo urbano, é urgente a criação de novas estruturas pastorais, visto que muitas delas nasceram em outras épocas para responder às necessidades do âmbito rural. ${ }^{8}$

Reconhecendo a complexidade de uma eclesiologia voltada para a missão evangelizadora e não para a "manutenção" pastoral dentro de estruturas antiquadas e ineficientes, este artigo propõe uma reflexão sobre as Comunidades Eclesiais de Base, que foram mencionadas na Conferência de Aparecida, como mais uma forma de ser Igreja. Uma Igreja preocupada com a evangelização, principalmente, dos excluídos de nossa sociedade.

As CEBs foram e continuam sendo, fundamentalmente uma experiência de vida eclesial, onde se dá uma combinação profícua do trabalho entre clero e leigos. "Sob formas novas, respondendo a outras exigências e condições sócio culturais, assistimos ao aparecimento de leigos, líderes que assumem papel relevante na vida eclesial". ${ }^{9}$ A comunidade, a partir de uma leitura sistemática do Evangelho, entendendo a sua realidade, busca soluções para seus problemas por sua própria conta. A leitura comunitária da Palavra de Deus, e a partir daí a ação transformadora de cada participante, é o que determina sua pertença às CEBs. A beleza e a graça de Deus manifestaram-se no desenvolvimento espontâneo das comunidades. "Teologicamente significam uma nova experiência eclesiológica, um renascer da própria Igreja e por isso uma ação do Espírito no horizonte das urgências de nosso tempo". ${ }^{10} \mathrm{Na}$ década de (19)70, a CNBB, reconhecendo as particularidades das CEBs, através de seus documentos sobre elas, propõe e incentiva esta nova

6 DAp. n. 518a.

7 DAp. n. 518c.

8 DAp. n. 173.

9 TEIXEIRA, Faustino Luiz Couto. A gênese das ceb’s no Brasil. São Paulo: Paulinas, 1988, p. 30 .

${ }^{10}$ PAULO VI. Discurso de encerramento do sínodo dos bispos (1974). Revista Eclesiástica Brasileira. Petrópolis: Vozes, n. 34, 1974, p. 945. 
forma de ser Igreja, apesar de não fazer uma forte recomendação para a sua proliferação ${ }^{11}$. Finalmente é importante reforçar que as CEBs, surgiram onde encontraram situações sociais, econômicas, políticas, religiosas e culturais, que se adequaram ao projeto de evangelização e eram conduzidas, animadas e acompanhadas por integrantes do clero, ainda que fosse um local de eloquente protagonismo leigo. "As CEBs constituem fundamentalmente um movimento de leigos". ${ }^{12}$ As CEBs foram uma forma de organização eclesiástica que surgiu efetivamente da base da sociedade brasileira, no meio do povo humilde e sem instrução, que não tinha a tradição de lutar por seus direitos e, muito importante, sem uma liderança nacional que se colocasse como carismática e salvadora.

\section{0 caminho das CEBs até Aparecida - as primeiras experiências}

O período pré-CEBs é aquele considerado entre o final dos anos (19)50, até 1965, e onde não havia uma definição prática de ações sociais ou de transformação dos problemas existenciais para os seus participantes. As comunidades de base nasciam de uma necessidade eclesial, como a falta de sacerdotes, ou da preocupação com o crescimento das igrejas protestantes nas zonas rurais. Neste período pré-Vaticano II, não havia preocupações com alguma novidade teológica e tampouco com articulações políticas. Apenas, e muito importante, houve o despertar de uma consciência social mais pela necessidade dos habitantes locais do que uma experiência a ser multiplicada. Período também anterior ao golpe militar de 1964, e da ditadura que se seguiu, limitadora das liberdades individuais do cidadão e que impedia a manifestação de ideias de qualquer ordem, a não ser a governamental. A hierarquia eclesiástica, atuante e estimulada de muitas maneiras, sentiu a necessidade de inovar no processo de evangelização. Com o passar do tempo e com o povo tomando consciência

\footnotetext{
${ }^{11}$ CONFERÊNCIA NACIONAL DOS BISPOS DO BRASIL. Diretrizes gerais da ação pastoral da Igreja do Brasil 1975-1978 (Documentos da CNBB n.4).

12 BOFF, Leonardo. Eclesiogênese. Petrópolis: Vozes, 1977, p. 10.
} 
de sua realidade, houve como consequência, a preocupação em transformar as estruturas sociais opressoras que mantinham a população carente em constantes condições de miséria. As transformações sociais não podem ser definidas de cima para baixo, pelo contrário, quando acontecem são sempre da base para o topo da pirâmide social. Seria inimaginável pensar, em uma sociedade como a brasileira onde o nível de participação popular era, até então, praticamente nulo, que uma ação com fundamentação eclesial evangelizadora suscitasse profundas transformações nos níveis político, econômico e mesmo religioso. No entanto, onde a Igreja-instituição desempenhou seu papel de evangelização, houve uma positiva mudança de rumos, muito melhor depois, do que antes, da experiência da prática eclesial comunitária. As experiências ocorridas no final da década de (19)50 em Barra do Piraí (RJ), com Dom Agnelo Rossi e do MEB (Movimento de Educação de Base), com Dom Eugenio Sales, em Natal (RN), são geralmente citadas como percussoras das CEBs.

\subsection{A experiência de Barra do Piraí (RJ)}

Devido à falta crônica de sacerdotes e, com isso, a população ficar desassistida, e ainda com o crescimento das igrejas pentecostais, na época chamada de "igrejas dos crentes", o bispo da diocese de Barra do Piraí (RJ), Dom Agnelo Rossi, na segunda metade da década de 19(50), lançou um programa que formava e instruía os leigos para ocuparem algumas tarefas eclesiásticas e, desse modo, suprirem a falta de sacerdotes. Os leigos que soubessem ler tivessem boa vontade e quisessem ajudar a Igreja, recebiam um material catequético que deveriam ler na sua comunidade mas, de modo algum, comentá-lo ou interpretá-lo. "Dar a leigos morigerados, ${ }^{13}$ de boa vontade, o material necessário para que eles leiam. O catequista popular lê e não fala. É um leitor, não um pregador ou um improvisador". ${ }^{4}$ Pelas próprias palavras do idealizador do programa, D. Agnelo Rossi, os leigos só

\footnotetext{
${ }^{13}$ Morigerados - pessoas de vida exemplar - Novo dicionário AURÉLIO. Rio de Janeiro: Nova Fronteira.

${ }_{14}$ ROSSI, Agnelo. Uma experiência de catequese popular. Revista Eclesiástica Brasileira, Petrópolis: Vozes, n. 17, 1957, p.732.
} 
foram chamados pela necessidade, pela falta de sacerdotes e para que o trabalho pastoral fosse executado. Abriu-se mão de uma preparação mais acurada e profunda, a fim de se fechar uma lacuna. Mas já foi um começo, pois antes do Concílio Vaticano II, em uma Igreja totalmente clerical, uma diocese no interior do Rio Janeiro, já tomava um caminho alternativo para a solução de seus problemas pastorais de evangelização popular, baseado no trabalho dos leigos, ainda que "numa clara função de suplência que, por um lado, substitui o clérigo ausente, e por outro, o faz sempre nos estritos limites do quadro eclesiástico vigente" ${ }^{15}$

As comunidades assim formadas passaram a ocupar todos os povoados da diocese. Os lugares de encontro e formação deixaram de ser as capelas e passaram a ser os salões comunitários, onde a reunião sistemática vai organizar a vida da comunidade, discutir e procurar soluções para as demandas existenciais da população, tais como: cursos de alfabetização, de corte e costura, mutirões para a construção de outros salões, organização da arrecadação de recursos. A experiência originária de uma necessidade pastoral passa para a reflexão e o agir de uma experiência de vida. O crescimento dos núcleos comunitários foi expressivo. "Chegaram a funcionar na diocese mais de 475 núcleos”. ${ }^{16}$

O clero, desde o início, procurou não perder o controle sobre os movimentos dos leigos. "O simples fato de não se permitir ao catequista acrescentar nada, nem comentar o que leu, denota o receio, por parte do clero, de ver limitado seu poder deliberativo em referência às questões da Igreja”. ${ }^{17}$ Mas a dinâmica apresentada pela nova situação não poderia ser dominada por quem quer que fosse. Em uma Igreja animada pelo Espírito Santo, podemos pretender saber como se inicia um processo, mas dificilmente, após iniciado, termos o controle sobre ele; foi o que aconteceu em Barra do Piraí. O processo, quando incorporado pelos seus participantes, ganha uma dinâmica própria. A

${ }^{15}$ AZEVEDO, Marcello. Comunidades Eclesiais de Base e Inculturação da Fé. São Paulo: Loyola, 1986, p. 43.

16 TEIXEIRA, Faustino Luiz Couto. A gênese das ceb's no Brasil. São Paulo: Paulinas, 1988, p. 58 .

17 Ibid., p. 59. 
influência e a liderança desses agentes de pastoral sobre a população são fáceis de perceber, além do que, tem o beneplácito do clero, "falam em nome do clero". "É interessante a experiência da missa sem padre, semanal e leiga. Talvez seja o primeiro germe dos cultos semanais realizados em determinadas CEBs". ${ }^{18}$

A nova situação não foi uma oposição à Igreja existente e tradicional, mas foi a descoberta de um papel mais ativo do leigo na sociedade, inclusive na Igreja, antes dominada hegemonicamente pelo sacerdote. Trata-se da descoberta de sua importância social e de seu protagonismo na mudança dessa realidade social estruturalmente injusta. Não devemos perder de vista que isso aconteceu, no interior do Brasil, antes do Vaticano II, em uma diocese cujo bispo, anos mais tarde, cardeal, será rotulado de conservador. Na experiência pastoral de Barra do Piraí, houve uma quebra de paradigmas, onde se destaca a “importância dos salões comunitários em substituição às capelas, nos salões a vida comunitária se organizava, com a catequese, o ensino, o corte e costura; houve a quebra entre o sagrado e o profano, isto é altamente significativo". ${ }^{19}$

Porém verificava-se com o leigo, assim como com o sacerdote, a passividade do povo, herança de sua formação cultural. Tudo era feito para o povo e em nome dele não cabendo a ele, porém, qualquer iniciativa maior. Este aspecto vai ser radicalmente modificado nas CEBs. Em Barra do Piraí, o diferencial foi a atitude da hierarquia, a oportunidade da participação do leigo em conjunto com o clero. Essa experiência será determinante no futuro, para a vivência nas CEBs e irá incorporar o elemento central da corresponsabilidade e criatividade: a presença ativa do leigo no esforço da evangelização, a vida e a continuidade da Igreja no povo, mesmo sem a presença do padre. ${ }^{20}$ Além disso, essa experiência de vida cria uma consciência na população em se autogerir ou no mínimo, um esforço de uma ajuda mútua para progredir dentro da comunidade, através de seus próprios meios e de seus próprios membros. Em um país onde a prática do clientelismo

\footnotetext{
${ }^{18}$ Ibid., p. 59.

19 Ibid., p.60.

${ }^{20}$ AZEVEDO, Marcello. Comunidades Eclesiais de Base e Inculturação da Fé. São Paulo: Loyola, 1986, p. 44.
} 
era comum e corrente, só esse fato já seria digno de nota e mereceria ser replicado. Finalmente, a experiência de Barra do Piraí levou os leigos, a entrar em contato direto com a Sagrada Escritura, ainda que lhe fosse proibido interpretá-la, tarefa destinada apenas aos padres e bispos, mas já era uma ação inusitada, valorizada e significativa.

\subsection{0 movimento de Natal (RN)}

"Qualquer plano de desenvolvimento que não se baseia na organização de comunidades - com uma efetiva participação de seus membros - e na preparação de seus líderes será extremamente difícil de concretizar-se". ${ }^{21}$ O Movimento de Natal (RN) foi o primeiro e o mais consistente programa de alfabetização popular executado no Brasil. Lembrando que, naquela época (1950), a taxa de analfabetismo no Nordeste era superior a $60 \%$ da população. A experiência levada a efeito por D. Eugênio Sales, bispo auxiliar de Natal, através das escolas radiofônicas, levava para as classes mais desassistidas não apenas a alfabetização, mas também, aspectos sociais, comunitários, religiosos e de conscientização política. O Movimento de Natal também nasceu de uma necessidade, esta material, da visão da realidade de miséria em que vivia grande parte da população nordestina e da preocupação de alguns padres em fazer algo para mudar aquele estado de coisas. "Nas reuniões do clero, discutem-se as possibilidades de ação efetiva por parte da Igreja ante o alarmante índice de analfabetismo, como também das péssimas condições de moradia, alimentação e saúde da população”. ${ }^{22}$

Um grande número de leigos e padres aliou-se neste esforço comum, mesmo sem um pensamento estratégico organizado e produtivo. Em 1958, após uma grande seca, onde o Arcebispo de Natal denuncia ao governo as explorações e abusos do DNOCS (Departamento Nacional de Obras contra as Secas), um órgão do governo federal, é que se organizou o Movimento de Natal que teve três objetivos: a

${ }^{21}$ SALES, Eugênio. A Igreja na América Latina e a promoção humana. Revista Eclesiástica Brasileira, vol. 28, fasc. 3, 1968, p. 545.

22 TEIXEIRA, Faustino Luiz Couto. A gênese das ceb's no Brasil. São Paulo: Paulinas, 1988, p. 61. 
educação de base, a transformação das estruturas políticas, sociais e econômicas, e a educação religiosa das populações mais carentes..$^{23} \mathrm{O}$ principal meio de divulgação empregado foi o radio, "para alfabetizar, catequizar e promover as pessoas isoladas das cidades, aos domingos, a comunidade - sem padre - se reunia em torno do rádio para participar do culto que o bispo presidia”. ${ }^{24}$ Nos programas radiofônicos do Movimento se passava não apenas as matérias para a alfabetização, mas também noções de problemas sociais, comunitários, religiosos e de conscientização política. “Também aqui encontramos a semente de algo essencial às CEBs: a vinculação de religião e vida, a concepção integral de evangelização, que passa pela totalidade do homem". ${ }^{25}$ Foi um enorme sucesso essa experiência radiofônica. Ela se estendeu pelo Nordeste, Norte e Centro-Oeste do país. O movimento de educação de base, além de transmitir a educação formal, devia zelar pelo desenvolvimento econômico e espiritual do povo de cada região. ${ }^{26}$

O Movimento de Natal e a sua educação de base foram pioneiros de várias formas no Brasil. A Igreja se antecipou a qualquer outro programa governamental de educação e de alfabetização. Incorporou técnicas de educação e conscientização de cidadania, em uma época em que esse vocábulo não fazia parte do cotidiano e, principalmente, se preocupou com uma educação integral do ser humano, no sentido de uma educação libertadora, baseada na obra de Paulo Freire. "Toda essa ordem de ideias, como os programas, métodos e ação, que as concretizam, terão mais tarde e de modo reflexo, grande influência sobre a prática pedagógica pastoral das CEBs”. ${ }^{27}$

Através do incentivo de um bispo, futuro cardeal e considerado conservador, e de sua diocese, modificou-se a relação da Igreja com o mundo do trabalho das classes operárias urbanas e rurais em uma

\footnotetext{
${ }^{23}$ Ibid., pp. 61-62.

${ }^{24}$ PUCCI, Bruno. A nova práxis educacional da igreja (1968-1979). São Paulo: Paulinas, 1984, p. 127.

${ }^{25}$ AZEVEDO, Marcello. Comunidades Eclesiais de Base e Inculturação da Fé. São Paulo: Loyola, 1986, p. 45.

${ }^{26}$ TEIXEIRA, Faustino Luiz Couto. A gênese das ceb’s no Brasil. São Paulo: Paulinas, 1988, p. 62.

${ }^{27}$ AZEVEDO, Marcello. Comunidades Eclesiais de Base e Inculturação da Fé. São Paulo: Loyola, 1986, p. 45.
} 
das regiões mais pobres do país que, no decorrer da história, sempre foram marginalizadas pelas elites dominantes, além de combater as ideias fatalistas em relação à pobreza.

O Movimento de Natal rejeitará, como sendo sub-humana, qualquer situação de miséria. A atuação da Igreja no campo social, sua intervenção contra as situações de exploração do homem será compreendida como sendo legítima. ${ }^{28}$

A visão pastoral do Movimento de Natal não se pautou pela política partidária e muito menos por uma ideologia econômica. O que o Movimento fez foi estimular a mobilização popular pela alfabetização, pela importância do voto e dos sindicatos, na defesa dos direitos e reivindicações dos trabalhadores. O Movimento não avançou na direção de propor mudanças nas estruturas sociais opressoras. Admitindo-se toda a positiva e benéfica influência das lideranças leigas, ainda assim, o Movimento teve clara direção do clero. Os leigos puderam caminhar, até onde a hierarquia achava prudente. "A perspectiva centrista, a disciplina em matéria social e política, o papel limitado reservado ao leigo foram alguns dos dados que o Movimento de Natal não conseguiu superar". ${ }^{29}$

Duas grandes motivações conjunturais, podemos notar nas ações evangelizadoras até agora descritas: a primeira é interna à Igreja: falta de sacerdotes, crescimento das igrejas pentecostais e a necessidade de se levar a fé católica para uma população pobre, marginalizada, afastada dos grandes centros. Esta realidade leva parte da Igreja a repensar suas ações pastorais e sua prática religiosa, abrindo mão do tradicionalismo, do poder da classe abastada e criando novos métodos revolucionários. A segunda motivação é social, a leitura de uma realidade injusta e os desafios para transformá-la. Em ambos os casos, surgiram buscas de novos caminhos, de nova forma de se viver a Igreja e uma mudança na participação do leigo na vida eclesial dessas comunidades. ${ }^{30}$

\footnotetext{
${ }^{28}$ TEIXEIRA, Faustino Luiz Couto. A gênese das ceb’s no Brasil. São Paulo: Paulinas, 1988, p. 65.

${ }^{29}$ Ibid., p. 67.

${ }^{30}$ PUCCI, Bruno. A nova práxis educacional da igreja (1968-1979). São Paulo: Paulinas, 1984, pp.127-128.
} 


\section{30 período de crescimento das CEBs (1965-1985)}

A partir dessas primeiras experiências de evangelização, o clero brasileiro se sentiu ainda mais estimulado após o clima de abertura que se seguiu ao Concílio Vaticano II. Dentro da nova eclesiologia nascida nas sessões conciliares, as comunidades de base passam a ser mencionadas e estimuladas em vários importantes documentos eclesiásticos que se seguem ao concílio: o Primeiro Plano Pastoral de Conjunto (PPC) emitido pela CNBB em 1965, dizia:

Faz-se urgente uma descentralização da paróquia, não necessariamente no sentido de criar novas paróquias jurídicas, mas de suscitar e dinamizar, dentro do território paroquial, comunidades de base (como as capelas rurais) onde os cristãos não sejam pessoas anônimas que apenas buscam um serviço ou cumprem uma obrigação, mas sintam-se acolhidos e responsáveis, e delas façam parte integrante, em comunhão de vida com Cristo e com todos os seus irmãos. ${ }^{31}$

Na Conferência de Medellín em 1968, o documento explicita e incentiva a criação das comunidades eclesiais de base:

Procurar a formação do maior número possível de comunidades eclesiais nas paróquias, especialmente rurais ou de marginalizados urbanos. Estas comunidades devem basear-se na Palavra de Deus realizar-se, enquanto possível, na celebração eucarística sempre em comunhão e sob a dependência do Bispo. A comunidade se formará na medida em que seus membros tiverem um sentido de pertença (de "nós") que os leve a ser solidários numa missão comum, numa participação ativa, consciente e frutuosa na vida litúrgica e na convivência comunitária. ${ }^{32}$

A CNBB voltará a incentivar a criação das CEBs em seu documento de 1974:

\footnotetext{
${ }^{31}$ CONFERÊNCIA NACIONAL DOS BISPOS DO BRASIL. Plano Pastoral de Conjunto 1966 1970 Edição 2004, p. 29.

32 CONSELHO EPISCOPAL LATINO AMERICANO. A Igreja na atual transformação da América Latina à luz do Concílio. 8. ed, Petrópolis: Vozes, 1985, pp. 92-93.
} 
Um dos desafios da ação pastoral no Brasil é, certamente, a multiplicação das "comunidades de base", que possam responder ao anseio do povo para uma vida plenamente eclesial, alimentada pela palavra de Deus e os sacramentos, principalmente a Eucaristia. ${ }^{33}$

A Conferência de Puebla (1979) procura uma definição definitiva para a experiência das CEBs:

A CEB, como comunidade integra famílias, adultos e jovens em estreito relacionamento interpessoal na fé. Como eclesial, é comunidade de fé, esperança e caridade, celebra a palavra de Deus e se nutre da Eucaristia, ponto culminante dos demais sacramentos; realiza a palavra de Deus na vida, mediante a solidariedade e o compromisso com o mandamento novo no Senhor; torna presente e atuante a missão eclesial e a comunhão visível com os legítimos pastores, através do serviço de coordenadores aprovados. É de base por estar constituída por um pequeno número de membros como forma permanente e como célula da grande comunidade. ${ }^{34}$

As CEBs, como experiência evangelizadora, cresceram vigorosamente no Brasil nas décadas de 70 e 80. Em 1975 deu-se o primeiro encontro intereclesial de CEBs, ocorrido em Vitória (ES). Desde então, novos encontros veem ocorrendo no intervalo entre três a quatro anos. O último, o $13^{\circ}$ encontro, foi em janeiro de 2014 em Juazeiro do Norte (CE). Porém, a partir da década de 80 houve uma falta de estímulo por parte da hierarquia para com as CEBs. Fundamentalmente a Igreja-instituição passa a desestimular uma prática eclesiástica que saiu do Vaticano II, a de uma Igreja ministerial, participativa do Povo de Deus. Volta-se para uma Igreja sacerdotal e sacramental, onde o centro não é mais o povo, a assembleia de fieis, mas o clero. Em 1984 e em 1986, a Congregação para a Doutrina da Fé emite dois documentos, fazendo críticas à Teologia da Libertação, cuja prática, estava corretamente

33 CONFERÊNCIA NACIONAL DOS BISPOS DO BRASIL. Diretrizes Gerais da Ação Pastoral da Igreja no Brasil - 1975/1978. Cap. 3, 2.2. Disponível em: <www.cnbb.org.br/documento_geral/A\%20-\%20DIRETRIZES\%20GERAIS.pdf>.

${ }^{34}$ CONSELHO EPISCOPAL LATINO AMERICANO. Documento de Puebla , n. 641, disponível em: <www.celam.org/conferencias/Documento_Conclusivo_Puebla.pdf $>$. 
associada às $\mathrm{CEBs}^{35}$. A Cúria Romana deixa bem claro que as comunidades de base devem estar subordinadas, como qualquer movimento, à hierarquia diocesana e paroquial, dentro do mais puro centralismo eclesiástico. Com isso, mesmo continuando a existir, as CEBs perdem sua forma mais importante de ser uma comunidade de iguais sem liderança oficial, uma nova forma de ser Igreja, onde a preocupação maior é com a evangelização, e se tornam mais um movimento paroquial. A utopia se desvaneceu, os pobres voltam para os seus lugares, fora das prioridades espirituais e temporais da sociedade e da Igreja e os leigos, clericalizados, são subservientes ao clero.

\section{As CEBs na Conferência de Aparecida}

Aparecida procurou retomar o caminho eclesiológico iniciado pelo Vaticano II, buscando desenvolver e dar impulso a uma Igreja missionária ${ }^{36}$, que tem por objetivo converter cada cristão católico em discípulo missionário, além de voltar a proclamar a opção preferencial pelos pobres: "A Igreja necessita de forte comoção que a impeça de se instalar na comodidade, no estancamento e na indiferença, à margem do sofrimento dos pobres do Continente". ${ }^{37}$ Como prática operativa desta proposta, os bispos reafirmaram que a paróquia deve se tornar uma "comunidade de comunidades". ${ }^{38}$ Para isso acontecer a Conferência adverte, e de modo constante e incisivo, para a formação dos batizados, para que estes se tornem efetivamente, missionários:

\footnotetext{
${ }^{35}$ Em 1984, a Sagrada Congregação para a Doutrina da Fé publicou A Instrução sobre alguns aspectos da “Teologia da Libertação”, Libertatis Nuntius, disponível em: <http://www. vatican.va/roman_curia/congregations/cfaith/documents/rc_con_cfaith_doc_19840806_ theology-liberation_po.html>; em 1986 publica a Instrução Libertatis Conscientia sobre a liberdade cristã e a libertação, disponível em: <http://www.vatican.va/roman_curia/congregations/cfaith/documents/rc_con_cfaith_doc_19860322_freedom-liberation_po.html>. Este documento deve ser lido à luz do anterior. Ambos trazem a preocupação do Vaticano com os aspectos ideológicos marxistas, contidos na "Teologia da Libertação" e na sua prática pastoral.

${ }^{36}$ DAp. n. 347.

${ }^{37}$ DAp. n. 362.

${ }^{38}$ DAp. n. 170, 309.
} 
Deve-se cultivar a formação comunitária especialmente na paróquia. ${ }^{39}$

Se queremos que as paróquias sejam centros de irradiação missionária em seus próprios territórios, elas devem ser também lugares de formação permanente. ${ }^{40}$

Os melhores esforços das paróquias neste inicio de terceiro milênio devem estar na convocação e na formação de leigos missionários. ${ }^{41}$

O pároco deve estimular a criação de pequenas comunidades eclesiais, "são elas um ambiente propício para escutar a Palavra de Deus, para viver a fraternidade, para animar a oração, para aprofundar processos de formação na fé e para fortalecer o exigente compromisso de ser apóstolos da sociedade de hoje". ${ }^{42}$ É nas pequenas comunidades que se pode desenvolver a Nova Evangelização e aonde os batizados vivam como autênticos discípulos missionários. ${ }^{43}$ A Conferência destaca a urgência na reestruturação paroquial, menciona 0 fato do número de católicos estar diminuindo e, além disso, que poucos atendem à missa dominical. "Particularmente no mundo urbano, é urgente a criação de novas estruturas pastorais, visto que muitas delas nasceram em outras épocas para responder às necessidades do âmbito rural". ${ }^{44}$ Aparecida aponta para a necessidade urgente de uma nova evangelização, com novos métodos e novas ações criativas; a necessidade mais do que urgente de uma renovação da estrutura paroquial; a formação bíblica e teológica dos leigos e o estímulo na criação de pequenas comunidades. Parece claro que a evangelização de massa não é um caminho que a Conferência de Aparecida sugira. Dentro deste contexto, como a experiência das Comunidades Eclesiais de Base são vistas pelos bispos? Aparecida, em seu texto revisado e oficial, destaca as CEBs com alguns pontos positivos e também com

\footnotetext{
${ }^{39}$ DAp. n. 305.

${ }^{40}$ DAp. n. 306.

${ }^{41}$ DAp. n. 174.

${ }^{42}$ DAp. n. 308.

${ }^{43}$ DAp. n. 307.

${ }^{44}$ DAp. n. 175.
} 
algumas ressalvas. Primeiro reconhece as CEBs como uma célula importante de evangelização:

As Comunidades Eclesiais de Base têm sido escolas que têm ajudado a formar cristãos comprometidos com sua fé.... Medellín reconheceu nelas uma célula inicial de estruturação eclesial e foco de fé e evangelização. Puebla constatou que as pequenas comunidades, sobretudo as comunidades eclesiais de base, permitiram ao povo chegar a um conhecimento maior da Palavra de Deus, ao compromisso social em nome do Evangelho, ao surgimento de novos serviços leigos e à educação da fé dos adultos. ${ }^{45}$

Mas, no mesmo tópico o documento ressalta que Puebla adverte que "não tem faltado membros de comunidade ou comunidades inteiras que, atraídas por instituições puramente leigas ou radicalizadas ideologicamente, foram perdendo o sentido eclesial”. ${ }^{46}$ A Conferência considera também que as CEBs "já demonstraram seu compromisso evangelizador e missionário entre os mais simples e afastados, e são expressão visível da opção preferencial pelos pobres". ${ }^{47}$ Mas deixa bem claro, também, que elas devem se inserir no projeto de pastoral diocesana e junto com os demais grupos paroquiais, associações e movimentos, contribuir para a revitalização das paróquias. Ou seja, em seu texto publicado, Aparecida não avança para uma referência destacada das CEBs como uma célula importante, diferenciada, na evangelização: "Como resposta às exigências de evangelização, junto com as comunidades eclesiais de base, existem outras formas válidas de pequenas comunidades, de movimentos, grupos de vida, de oração e de reflexão da Palavra de Deus" ${ }^{48}$ O texto aprovado cortou uma boa parte do que os bispos originalmente propuseram sobre a capacidade das CEBs como célula de evangelização. No texto original, os bispos escreveram:

Queremos decididamente reafirmar e dar novo impulso à vida e à missão profética e santificadora das CEBs no seguimento missionário

\footnotetext{
45 DAp. n. 178.

46 DAp. n. 178.

47 DAp. n. 179.

48 DAp. n. 180.
} 
de Jesus. Elas foram uma das grandes manifestações do Espírito na Igreja da América Latina e do Caribe depois do Vaticano II. ${ }^{49}$

Outro trecho cortado do documento aprovado pelos bispos enfatizava a eficácia missionária das CEBs estimulando seu desenvolvimento:

Depois do caminho percorrido até agora, com conquistas e dificuldades, é hora de uma profunda renovação dessa rica experiência eclesial em nosso continente, para que elas não percam sua eficácia missionária, mas a aperfeiçoem e desenvolvam de acordo com as exigências sempre novas dos tempos. ${ }^{50}$

Porém, mesmo com os cortes que tiraram a ênfase da importância das Cebs como força evangelizadora, o estímulo a elas permanece no Documento de Aparecida, reconhecendo seus frutos na evangelização junto aos pobres. Seguindo o pensamento de mudanças, os bispos são enfáticos em dizer que é necessário reestruturar as já ineficientes estruturas paroquiais em busca de uma nova evangelização. ${ }^{51} \mathrm{O}$ trabalho de evangelização deve levar em conta as condições sociais, econômicas, políticas e religiosas onde o evangelizador/missionário irá atuar. Isto não tem novidade alguma. A novidade está em como fazer e quem irá fazer e não o que fazer. A experiência evangelizadora das CEBs, principalmente nas décadas de 60 e 70 do século passado, foi uma verdadeira luz para aqueles que participaram. Primeiro, para os que conduziram a ação evangelizadora, reconhecendo toda a precariedade da vida da população. Uma população desassistida, sem qualquer participação nas decisões sobre política, economia ou religião que influenciavam sua vida. Atuaram em áreas onde a população não tinha formação religiosa, educacional e eram economicamente excluídos, mas tinham uma grande piedade e religiosidade popular. Os exemplos estudados mostram que, a direção partiu de um princípio de participação, de companheirismo, de democracia entre clero e

${ }^{49}$ COMBLin, José. O projeto de Aparecida. Vida Pastoral. São Paulo: Paulus, n. 258, 2008, p. 4.

${ }^{50}$ MUÑOZ Ronaldo. As mudanças no Documento de Aparecida in: AMERÍNDIA (Org.). $V$ Conferência de Aparecida. Renascer de uma esperança. Montevideo: Ameríndia, São Paulo: Paulinas, 2007, p. 290-291.

${ }^{51}$ DAp. n. 170. 
leigos. Abandonou-se o binômio do mando e da obediência cega, do leitor-ouvinte, do professor-aluno, do padre-leigo, do governo-povo, do eu mando e vocês obedecem. A experiência evangelizadora das CEBs pressupõe, em primeiro lugar, o entendimento das condições reais de vida do povo a ser evangelizado, e com objetivos pelo menos de médio prazo. Mais ainda, com o testemunho de padres e religiosas vivendo no local onde viviam os seus fieis, com as mesmas dificuldades e precariedades, houve uma convivência, uma harmonia, uma cumplicidade entre o evangelizador e o evangelizado. Em síntese, vivia-se o que se rezava e se rezava o que se vivia. Resistiu-se à tentação do poder, do ter, de construir, de crescer, de se tornar paróquia, de se ter mais estruturas burocráticas, mais visibilidade, mais “clientes”. A qualidade era preferível à quantidade. $\mathrm{O}$ modelo procurou aprofundar mais o Evangelho em poucos, do que a catequizar superficialmente muitos. A experiência equivale a outros momentos do passado da Igreja onde tudo parece caminhar em sendas contrárias aos caminhos do Senhor e, por obra do Espírito Santo, surgem esperanças de reconduzir a Igreja pelo caminho adequado, com os profetas, os mártires, os fundadores das ordens religiosas, santos e santas que, com seus exemplos de vida cristã levantaram a Igreja do Senhor Jesus. Assim também foi com as Comunidades Eclesiais de Base. Inegavelmente, em função de várias circunstâncias históricas, houve uma excessiva politização da ação evangelizadora. Não foram poucos, os que abandonaram a convivência comunitária, para se dedicarem a partidos políticos e se tornaram políticos profissionais. Estes, não reconheceram que as CEBs devem ser um local de discussão política para o bem comum da comunidade, mas não uma célula partidária. Erros existiram no passado e devem ser evitados no presente.

A Igreja-instituição, nesse período de novos ares, também proporciona os meios teóricos e municia suas bases de documentos e conceitos bíblicos e teológicos que indicavam uma mudança de rumos. Tanto através da CNBB como do CELAM, os documentos dão subsídios para uma reforma nas estruturas já ultrapassadas, inadequadas e ineficientes. Todos aqueles que têm acesso a tais documentos sabem o que se deve fazer, mas poucos sabem como fazer, ou pior se sabem, não querem fazer. Como vimos a evangelização dá muito trabalho, que 
deve ser repetido, muitas vezes; quando se pensa que alguma etapa foi superada, volta-se para trás pois, ao contrário do que se pensava, alguns obstáculos não foram devidamente superados. A evangelização, que tem por objetivo levar a uma mudança integral do ser humano, requer total despojamento e foco na ação dos empreendedores. Outro aspecto muito claro, que a experiência demonstrou, é que a evangelização deve ser feita a partir dos pobres, das periferias, dos lugares remotos. Aqui entra um novo elemento. A evangelização precisa de um modelo adequado à região a ser evangelizada, portanto não surtirá total efeito se utilizados os canais de mídia massiva ou de grande exposição que são, por excelência, superficiais. A evangelização em uma pequena comunidade deve ser liderada por um elemento do clero que deve estar desapegado do fator econômico, pois viver como pobre é estar na pobreza real. A sociedade capitalista neoliberal em que vivemos, propaga o ganho financeiro, o status, o acúmulo de bens, e isto não se adéqua a este projeto de evangelização. Encontrar pessoas preparadas e dispostas ao sofrimento material para ficar ao lado dos pobres, com o objetivo de evangelizá-los e transformá-los lutando contra as estruturas opressoras é um enorme desafio. Será que isso ainda atrai membros representativos do clero? Ou o "que teme certa hierarquia católica é simplesmente que os pobres venham a atingir sua "maioridade" na Igreja e passem a ser sujeitos ativos na própria Igreja?”. ${ }^{2}$

Não podemos deixar de notar, que o Documento de Aparecida reconhece o labor das CEBs no passado, mas levanta um questionamento para o seu emprego com célula evangelizadora para o futuro:

Puebla constatou que as pequenas comunidades, sobretudo as comunidades eclesiais de base, permitiram ao povo chegar a um conhecimento maior da Palavra de Deus, ao compromisso social em nome do Evangelho, ao surgimento de novos serviços leigos e à educação da fé dos adultos, no entanto, também constatou "que não têm faltado membros de comunidade ou comunidades inteiras

\footnotetext{
${ }^{52}$ MUÑOZ Ronaldo. As mudanças no Documento de Aparecida in: AMERÍNDIA (Org.). $V$ Conferência de Aparecida. Renascer de uma esperança. Montevideo: Ameríndia, São Paulo: Paulinas, 2007, p. 292.
} 
que, atraídas por instituições puramente leigas ou radicalizadas ideologicamente, foram perdendo o sentido eclesial". ${ }^{53}$

O egoísmo da sociedade atual, o poder centralizador, as modificações na política e na economia, a excessiva politização, a cultura da celebridade, da sociedade do espetáculo, de ter sucesso para as grandes massas, para as grandes mídias, aparentemente tiraram o brilho das CEBs, que retrocederam como modo de ser Igreja, apesar de ainda estarem ativas pelo menos nominalmente.

\section{Conclusão}

A Igreja Católica no Brasil tem grandes desafios a vencer: evangelizar em uma sociedade cada vez mais secularizada, urbana e fluída. As CEBs, como instrumento de evangelização, não tiram o trabalho nem o valor do serviço paroquial, dos movimentos ou das pastorais. O que precisamos entender é que a paróquia atende aos fieis que já foram evangelizados, ou que, atraídos pelo carisma de algum movimento ou pastoral, procura sua estrutura, para atendê-lo em geral em suas vicissitudes espirituais. Caberá naturalmente, ao pároco e sua equipe, a missão de aprofundar a fé daquela pessoa, oferecendo trabalhos pastorais, formação, aprofundamento bíblico, conhecimento da Doutrina Social da Igreja, etc. A estrutura paroquial é, e continuará sendo, necessária ainda que se limite a ser sacramental e celebrativa. As CEBs são em sua essência missionárias, ou seja, devem sair dos limites do templo em busca das ovelhas perdidas e que desejem a salvação.

Não é de admirar que alguns grupos muito ligados às CEBs, aos grupos de leitura popular de Bíblia e aos movimentos sociais tenham experimentado certa perplexidade ao constatar que as CEBs são consideradas pelo Texto de Aparecida como um grupo ou movimento a mais, entre outros. Perplexidade essa que certamente se prende à

\footnotetext{
53 DAp. n. 180.
} 
pretensão das mesmas CEBs, persistente ao longo de décadas, de ser não mais grupo de Igreja, mas uma nova forma de ser Igreja. ${ }^{54}$

É possível que uma pessoa evangelizada e participante de uma CEB não se acomode em uma estrutura paroquial, mas isso não significa, necessariamente, que a paróquia deva mudar. 0 que deve mudar é o nosso olhar para a realidade, quem evangeliza não pode cuidar de uma paróquia, com toda a sua burocracia, seus horários, e seus vários compromissos cotidianos. A evangelização requer tempo integral e total dedicação, as CEBs não precisam ou não devem estar ligadas umbilicalmente a uma paróquia. Os trabalhos de uma comunidade de base e de uma paróquia deveriam ser sinérgicos e complementares, mas não dependentes.

A Igreja do futuro será uma Igreja que se constituirá de baixo para cima, por meio de comunidades de base de livre iniciativa e associação. Temos de fazer todo o possível para não impedir esse desenvolvimento, mas antes promovê-lo e orientá-lo corretamente. ${ }^{55}$

Que falar de um futuro projeto de evangelização, a partir de Aparecida? Primeiro deve-se compreender profundamente as condições sociais, políticas e econômicas do país.

A Igreja deveria lutar com mais ênfase pela formação de uma consciência social em vista de uma sociedade mais humana, componentes religiosos ou morais que não incidem no bem ao próximo não tem significado no mundo de hoje. ${ }^{56}$

Apesar de uma melhora sensível em termos sociais, o Brasil ainda está muito longe de uma situação ideal: a situação de educação básica ainda é precária, cerca de 9\% da população ainda é analfabeta e $25 \%$ considerada analfabeta funcional, dados do censo de 2010; $50 \%$ dos domicílios brasileiros não têm saneamento básico; a situação na saúde pública é calamitosa; a violência deixou de ser urbana e passou a ser

\footnotetext{
${ }^{54}$ BINGEMER, Maria Clara Lucchetti. Eclesialidade e cidadania o lugar do laicato no Documento de Aparecida. Revista Eclesiástica Brasileira. Petrópolis: Vozes, v. 67, fasc. 268, 2007, p. 993.

${ }_{55}$ RAHNER, Karl. Estruturas em mudança: tarefa e perspectivas para a Igreja. Petrópolis: Vozes, 1976, p. 97.

${ }^{56}$ MIRANDA, Mario de França. Uma Igreja em processo de renovação. Revista Eclesiástica Brasileira. Petrópolis: Vozes, fasc 286, 2012, p. 393.
} 
geral, cresce o consumo indiscriminado de drogas; as grandes cidades carecem de transporte coletivo e sofrem com o trânsito e a poluição; a corrupção é endêmica e a classe política é vista como uma tragédia nacional. Na economia o país continua dependente do mercado externo, ou seja, segue sendo um país periférico; a má distribuição de renda continua a ser uma das mais injustas do mundo, apesar de esforços terem sido feitos para minimizar esse mal, ele continua; o país sofre com uma alta taxa de tributação, e quem mais sofre são os mais pobres, pois não há retorno por parte do governo, em benefícios para os necessitados. No campo político tivemos inegáveis avanços. Apesar dos pesares, após a queda da ditadura e a aprovação da Constituição de 1988, o Brasil vive uma democracia em pleno estado de direito. Estamos muito longe de uma qualidade aceitável de cidadania, pois, a classe política simplesmente não governa para o povo, mas sim para seus próprios interesses eleitorais, as estruturas econômicas injustas continuam, as elites seguem oprimindo. Entretanto, há uma verdadeira liberdade de expressão, embora, ela ainda não influa o suficiente, mas já há mecanismos para o povo se fazer ouvir. 0 cidadão brasileiro está aprendendo a se manifestar, a participar da vida nacional, a exigir seus direitos. Essa vontade de participação se faz sentir também no campo religioso. Mesmo de modo tímido o fiel quer participar mais, já não se contenta com explicações pré-formatadas e fora do contexto. Neste campo o trabalho de evangelização será muito mais difícil, pois hoje, o cidadão comum tem ideias próprias que estão além da compreensão de uma Igreja com conceitos antigos; se ele não concorda, simplesmente não segue. A sociedade já pode viver sem as referências religiosas do passado, hoje já não é mal visto quem não se casa na igreja, ou simplesmente não se casa nem no civil, ou não batiza seus filhos, ou não se confessa. A sociedade brasileira está cada vez mais secularizada. Um trabalho de evangelização, hoje, requer muito mais dedicação, muito mais esforço e muito mais conhecimento do que no passado. As cidades são muito mais plurais, formam suas próprias “tribos”, cada qual com sua própria linguagem, muitas vezes sem relação entre si. Nada indica que esse fenômeno irá diminuir, mas ao contrário tende a aumentar. Assim, temos várias culturas em uma mesma região da cidade e, de novo, o trabalho do evangelizador, não 
poderá ser pasteurizado, pré-formatado, igual para todos. Isso não é nenhuma novidade histórica, acontece desde os tempos de são Paulo Apóstolo. O problema hoje em dia, é que temos a tentação de pensar em comunicação de massa, grandes auditórios, mídia eletrônica, internet, vender milhões de livros, educação massiva; isso pode ser sucesso no sistema capitalista neoliberal, mas não funciona como um projeto de evangelização, de transformação do individuo e da sociedade. Pela sua própria essência, aquele modelo é superficial, enquanto a evangelização precisa ser profunda, e neste sentido as comunidades de base representam o antissistema, a contramão da história de sucesso, como, aliás, foi o Ministério de Jesus de Nazaré, o Cristo; mais uma vez não há novidade, a novidade será segui-lo fielmente.

O Documento de Aparecida propõe em seu capítulo VII uma conversão pastoral e renovação missionária das comunidades, para isso estimula: ${ }^{57}$

- Nenhuma comunidade deve isentar-se de entrar decididamente, com todas as forças, nos processos constantes de renovação missionária e de abandonar as ultrapassadas estruturas que já não favoreçam a transmissão da fé;

- A conversão pessoal desperta a capacidade de submeter tudo ao serviço da instauração do Reino da vida;

- A pastoral da Igreja não pode prescindir do contexto histórico onde vivem seus membros. Sua vida acontece em contextos socioculturais bem concretos;

- Hoje mais do que nunca, o testemunho da comunhão eclesial e de santidade são uma urgência pastoral; a conversão pastoral de nossas comunidades exige que se vá além de uma pastoral de mera conservação para uma pastoral decididamente missionária;

- Os leigos devem participar do discernimento, da tomada de decisões, do planejamento e da execução;

- É aconselhável ter equipes próprias de animação e coordenação que permitam maior proximidade com pessoas e grupos que vivem na região.

${ }^{57}$ Doc. Ap. n. 365-372. 
Essas sugestões se encaixam no modelo de CEB já desenvolvido no Brasil. Rejuvenescer as CEBs será mais um desafio para a Igreja, desde que ela queira encará-lo. Significa ter seus melhores talentos, ou os mais bem preparados, despojados de qualquer tipo de riqueza ou ostentação, viver pobremente como tantos santos de outrora, trabalhar incessantemente para transformar uma população carente de tudo e não receber nada em troca, a não ser o infinito Amor de Deus e saber que está incluindo os evangelizados em seu Reino. As palavras do Pe. José Comblin, proferidas há mais de 40 anos, permanecem atuais e são um excelente resumo dos pontos acima; o difícil talvez seja, materializá-las:

Não se faz pastoral verdadeira a partir dos sonhos elaborados nos gabinetes dos intelectuais puros ou das burocracias. Faz-se numa comunidade real com forças reais. Essas forças não se fabricam nas oficinas de pastoral. Elas estão presentes na sociedade, ou não existem, nem poderão existir. ${ }^{58}$

\section{Bibliografia}

\section{Documentos magisteriais}

CONSELHO EPISCOPAL LATINO-AMERICANO. A Igreja na atual transformação da América Latina à luz do Concílio. 8. ed, Petrópolis: Vozes, 1985. . Documento de Aparecida. São Paulo: Paulinas/Paulus/ CNBB, 2007. CONFERÊNCIA NACIONAL DOS BISPOS DO BRASIL. Diretrizes gerais $d a$ ação pastoral da Igreja do Brasil 1975-1978.

. Plano Pastoral de Conjunto 1966-1970 Edição 2004.

\section{Livros}

AZEVEDO, Marcello. Comunidades Eclesiais de Base e Inculturação da Fé. São Paulo: Loyola, 1986.

\footnotetext{
${ }^{58}$ COMBLIN, José. Comunidades Eclesiais e Pastoral Urbana. Revista Eclesiástica Brasileira, Petrópolis: Vozes, v. 30, fasc. 120, 1970, p.787.
} 
BARBAGLIA, Mariano. Evolução das comunidades eclesiais de base. Petrópolis: Vozes, 1971.

BARBÉ, Domingos; RETUMBA, Emmanuel. Retrato de uma comunidade de base. 2. ed. Petrópolis: Vozes, 1971.

BARREIRO, Álvaro. Comunidades Eclesiais de Base e Evangelização dos Pobres. São Paulo: Loyola, 1977.

BOFF, Leonardo. Eclesiogênese. Petrópolis: Vozes, 1977.

BETTO, Frei. CEB's rumo a nova sociedade. São Paulo: Paulinas, 1983.

GONÇALVES, Paulo Sergio Lopes; BOMBONATTO, Vera Ivanise (Orgs.). Concílio Vaticano II: Análises e prospectivas. São Paulo: Paulinas, 2004.

MIRANDA, Mario de França. Igreja e sociedade. São Paulo: Paulinas, 2009.

PUCCI, Bruno. A nova práxis educacional da igreja (1968-1979). São Paulo: Paulinas, 1984.

RAHNER, Karl. Estruturas em mudança: tarefa e perspectivas para a Igreja. Petrópolis: Vozes, 1976, p. 97.

TEIXEIRA, Faustino Luiz Couto. A gênese das Ceb's no Brasil. São Paulo: Paulinas, 1988.

. Os encontros intereclesiais de CEBs no Brasil. São Paulo: Paulinas, 1996.

WANDERLEY, Luis Eduardo W. Democracia e Igreja Popular. São Paulo: Educ, 2007.

\section{Artigos}

BINGEMER, Maria Clara Lucchetti. Eclesialidade e cidadania o lugar do laicato no Documento de Aparecida. Revista Eclesiástica Brasileira. Petrópolis: Vozes, v. 67, fasc. 268, 2007, 977-1000.

COMBLIN, José. “Comunidades Eclesiais e Pastoral Urbana”. Revista Eclesiástica Brasileira, Petrópolis: Vozes, v. 30, fasc. 120, 1970, 783-828.

. “O projeto de Aparecida”. In: Vida Pastoral. São Paulo: Paulus, n. 258, 2008, 3-10.

MIRANDA, Mario de França. "Uma Igreja em processo de renovação”. Revista Eclesiástica Brasileira. Petrópolis: Vozes, fasc 286, 2012, 366-395.

MUÑOZ Ronaldo. As mudanças no Documento de Aparecida in: AMERÍNDIA (Org.). V Conferência de Aparecida. Renascer de uma esperança. Ameríndia, São Paulo: Paulinas, 2008.

PAULO VI. "Discurso de encerramento do sínodo dos bispos (1974)”. Revista Eclesiástica Brasileira. Petrópolis: Vozes, n. 34, 1974, 941-947. 
ROSSI, Dom Agnelo. “Uma experiência de catequese popular”. In: Revista Eclesiástica Brasileira, Petrópolis: Vozes, n. 17, 1957, 731-737.

SALES, Eugênio. "A Igreja na América Latina e a promoção humana”. Revista Eclesiástica Brasileira, vol. 28, fasc. 3, 1968, 537-554.

\section{Fontes digitais}

<www.celam.org/conferencias/Documento_Conclusivo_Puebla.pdf>.Documento de Puebla.

$<$ http://www.vatican.va/roman_curia/congregations/cfaith/documents/ rc_con_cfaith_doc_19840806_theology-liberation_po.html>; Instrução sobre alguns aspectos da "Teologia da Libertação", Libertatis Nuntius. $<$ http://www.vatican.va/roman_curia/congregations/cfaith/documents/ rc_con_cfaith_doc_19860322_freedom-liberation_po.html>. Instrução Libertatis Conscientia sobre a liberdade cristã e a libertação. 